América sin Nombre, n. ${ }^{\circ} 24$ (2020): 79-89

DOI 10.14198/AMESN.2020.24-2.07

ISSN: 1577.3442 / eISSN: 1989-9831

Fecha de recepción: 14/02/2019

Fecha de aceptación: 01/07/2019
Modo de citación de este artículo:

Salazar Anglada, Aníbal. «Poesía mexicana contemporánea: Diario de sueños (2011) o la madurez poética de Homero Aridjis». La nueva novela latinoamericana sin limites. Lise Segas y Félix Terrones (coordinadores). América sin Nombre, 24 (2020): 79-89, DOI: 10.14198/AMESN.2020.24-2.07

Link para este artículo: http://dx.doi.org/10.14198/AMESN.2020.24-2.07

\title{
Poesía mexicana contemporánea: Diario de sueños (2011) o la madurez poética de Homero Aridjis
}

\author{
Contemporary Mexican poetry: Diario de sueños (2011) \\ or Homero Aridjis' poetic maturity
}

\author{
Aníbal Salazar Anglada* \\ Universidad Ramon Llull
}

\section{Resumen}

El presente trabajo pone su atención en Diario de sueños, poemario de Homero Aridjis publicado en 2011, que revela la consagración del poeta mexicano, quien se da a conocer a finales de los años 50 y cuenta en su haber con una larga trayectoria compuesta de una treintena de títulos y decenas de poemas memorables. El artículo pone en valor algunas marcas definitorias de la poética aridjisiana, que alcanzan en este libro su más lograda expresión estética y que, en su conjunto, elevan la figura de Aridjis a la categoría de clásico vivo.

Palabras clave: Homero Aridjis, poesía mexicana contemporánea, geografías de la crítica, Diario de sueños

\begin{abstract}
This work focuses on Diario de sueños, a book of poems by Homero Aridjis published in 2011, which reveals how he truly established his reputation as a poet. The Mexican writer, who was knows at the end of the 1950s, has published approximately thirty books and dozens of memorable poems. This article highlights some defining features of Aridjisian
\end{abstract}

* Es doctor en Literatura Hispanoamericana por la Universidad de Sevilla. En la actualidad es profesor en la Universitat Ramon Llull de Barcelona. Los ámbitos de especialización en que se ha desarrollado su trayectoria como investigador son: la poesía hispanoamericana de los siglos XIX y xx; la historiografía y el canon literarios; poesía y exilio; y las relaciones transatlánticas, en especial el eje España-Argentina. Ha publicado diversos trabajos sobre Leopoldo Lugones, Jorge Luis Borges, Juan Gelman, Raúl Zurita, Gabriel Zaid, Homero Aridjis. En relación a este último, ha publicado recientemente en ediciones Cátedra (Col. Letras Hispánicas) una Antología poética (1960-2018) (2018). De este mismo autor ha realizado, en calidad de director, su portal en la Biblioteca Virtual Miguel de Cervantes: http://www.cervantesvirtual.com/portales/homero_aridjis/. En la corriente de los estudios transatlánticos, ha publicado algunos trabajos que abordan la participación de intelectuales hispanoamericanos en la Guerra Civil española: la novela del argentino Valentín de Pedro La vida por la opinión. Novela del asedio a Madrid (Sevilla: Renacimiento, 2014); y la serie de artículos y retratos del mismo autor reunidos en Cuando en España estalló la paz. Galería de condenados tras la Guerra Civil: escritores, periodistas y políticos (Sevilla: Renacimiento, 2014). Asimismo, es responsable de la edición de la novela inédita del escritor madrileño Diego San José titulada Por Dios y por España (Sevilla: Renacimiento, 2019). Actualmente participa en el proyecto El impacto de la Guerra Civil española en la vida intelectual de Hispanoamérica, coordinado desde la Universidad Complutense de Madrid por Niall Binns. En 2020, tiene previsto publicar el volumen Puerto Rico y la Guerra Civil española. La voz de los intelectuales (Madrid: Calambur). 
poetic art, which reach their highest aesthetic expression in this book and, as a whole, elevate the figure of Aridjis to the category of a living classic author.

Keywords: Homero Aridjis, Contemporary Mexican poetry, geographies of criticism, Diario de sueños

En marzo de 2011, en la editorial Fondo de Cultura Económica de México, que fundara en 1934 el insigne historiador Daniel Cosío Villegas, se daba a conocer el poemario Diario de sueños, del escritor Homero Aridjis (Contepec, Michoacán, 1940), poeta, novelista, dramaturgo, diplomático y activista medioambiental, viejo conocido en los círculos culturales mexicanos desde que iniciara su andadura intelectual a finales de los años 50. En aquel entonces, cuando era tan solo un aspirante a escritor, fue favorecido por Juan José Arreola y Octavio Paz, quienes, el primero desde el taller literario que impartía en los bajos del Centro Mexicano de Escritores (CME), y el segundo desde el lugar de Pontifex Maximus de las letras nacionales, teorizador de la modernidad y de la mexicanidad, intuyeron en el joven michoacano una de las voces más originales y prometedoras de la poesía mexicana contemporánea. Como tal, su nombre fue incluido en la archiconocida y muy importante antología Poesía en movimiento (México: Siglo XxI, 1966), urdida a cuatro manos por Octavio Paz, Alí Chumacero, José Emilio Pacheco y el propio Aridjis, quien, además, aparece abriendo la antología con un puñado de poemas ${ }^{1}$. Sin embargo, aquel muchacho llegado de provincias no era en 1966 un don nadie: en 1959, contra todo pronóstico, ganó una beca del CME; en 1964, se alzaría con el codiciado premio Xavier Villaurrutia por su libro Mirándola dormir, con un jurado compuesto por Octavio Paz, Carlos Pellicer, Rodolfo Usigli y Francisco Zendejas; y en el mismo año 66 en que se publica Poesía en movimiento, obtiene una beca de la prestigiosa John Simon Guggenhein Fundation.

La carrera poética de Aridjis ha sido desde entonces larga y fructífera. Los más maliciosos dirán que excesiva y desigual, pero lo cierto es que el nombre de Homero Aridjis ocupa un lugar destacado en la poesía contemporánea de México y, pese a las

1. La razón es simple: una de las peculiaridades que presenta esta antología es que está ordenada a la inversa, es decir, que comienza con los más jóvenes poetas del momento en aquellos años 60 y se cierra con los padres de la modernidad (Reyes, López Velarde, Tablada). Con 26 años, Aridjis es el poeta más joven de la antología, seguido de José Emilio Pacheco, Jaime Labastida, Óscar Oliva y Francisco Cervantes. trampas de la memoria, es difícil soslayar su obra — no solo la poética - en el esbozo de la historia de las letras mexicanas de la segunda mitad del siglo $\mathrm{xx}$, en un tiempo (los 60, los 70) en que las disputas culturales, capitaneadas y fagocitadas por las figuras, tan plausibles como intrigantes, de Octavio Paz y Carlos Fuentes, eran viscerales, siempre con trasfondo ideológico. Pero no solo hay que hablar de México: la obra de Aridjis ha sido traducida a varias lenguas, por supuesto a las que reconocemos ampliamente como «lenguas de cultura» (el inglés, el francés, el alemán), y, a la par de estas, a otras como el griego moderno y el neerlandés. El destacado papel de Aridjis al frente del Grupo de los Cien, una de las plataformas de lucha ambientalista más importantes de Latinoamérica que se fundó en 1985 con el apoyo de los principales intelectuales mexicanos y también de escritores y artistas que vivían en México entonces (Gabriel García Márquez, Leonora Carrington, pongamos por caso), así como de algunas figuras extranjeras de relieve en la lucha por el medioambiente (Lester R. Brown, Edward Goldsmith, Amory B. Lovins, entre otros); unido esto a los varios festivales internacionales de poesía que organizó el escritor en Morelia, capital del estado de Michoacán, y que convocó a poetas de la talla de Andrei Voznesenski, Allen Ginsberg, Günter Grass, Rafael Alberti, Marin Sorescu, Tadeusz Rozewicz; y, finalmente, como consecuencia de lo anterior, el hecho de que entre 1997 y 2003, por dos mandatos consecutivos, Aridjis ocupara la presidencia del PEN Club Internacional, todo ello confiere al nombre de Homero Aridjis una dimensión que excede las fronteras de México y del continente latinoamericano y se extiende por EE. UU. y Europa.

\section{El redescubrimiento en España de ese «otro Homero»}

En cambio, en España pareciera que es ahora cuando estamos descubriendo a Aridjis, ese «otro Homero» ${ }^{2}$.

2. El propio Aridjis, se diría que de forma inevitable, ha bromeado alguna vez sobre la coincidencia de su nombre con 
O cabría decir, mejor, «redescubriendo», si hacemos un poco de historia y acudimos a los archivos editoriales y a las hemerotecas. Hacia mitad de los años 70, el nombre de Aridjis y alguna muestra de su obra poética — su obra teatral y narrativa es más tardía, se inicia en los 80- nos llega a través de varias antologías. La primera de ellas vendría de la mano de Cristina Peri Rossi, quien por entonces vivía en Barcelona como exiliada tras zafarse de la dictadura militar que se instaló en Uruguay tras el golpe de Estado de Bordaberry. Un día, Esther Tusquets, entonces directora de Lumen, le pidió que le facilitara algunos nombres de autores latinoamericanos no muy conocidos en España, para darles cobertura. Peri Rossi pensó en un narrador y en un poeta; el primero, por entonces desconocido para el público español, era un compatriota de la escritora: Felisberto Hernández; y el segundo, Homero Aridjis, igualmente inédito en España. La antología, finalmente, se publicó en 1976. Para entonces, el mexicano había publicado ya varios libros de poemas: Los ojos desdoblados (1960), La tumba de Filidor (1961), Antes del reino (1963), Mirándola dormir (1964), Perséfone (1967), Ajedrez-Navegaciones (1969), Los espacios azules (1969); y otros libros más difíciles de encasillar, aunque bien podrían clasificarse como poesía en prosa: El poeta niño (1971) y El encantador solitario (1973). En este tiempo fecundo, Aridjis ya publicaba en los sellos editoriales más señeros de México: Joaquín Mortiz, Era, Siglo xxI, FCE. Peri Rossi, que muchos años después se referirá a la poesía de Aridjis como una escritura panerótica, estaba muy interesada no tanto por los poemarios más tempranos como por poemas extensos fuera de toda horma clásica, como Mirándola dormir o Perséfone, que rezuman un erotismo electrizante no frecuente en la poesía española en aquel entonces y que excedía el contexto erótico de los amantes (110).

En ese mismo año 1976, se publica en España otra antología poética a cargo de Ocnos Barral Editores, titulada Sobre una ausencia, que recoge partes de Mirándola dormir, Ajedrez-Navegaciones y El poeta niño. Poco después, en el 77 , vuelve a publicarse una antología del autor, esta vez en la madrileña editorial Akal. Pasado el tiempo, ya entrados en los

el del autor griego de la Ilíada y la Odisea. En su poema "Autorretrato a los cincuenta y cuatro años», del libro Ojos de otro mirar (1998), escribe: "En el comedor de mi casa / tuve mis primeros amores: / Dickens, Cervantes, Shakespeare / y el otro Homero». El guińo a este verso, pues, es el reverso de la broma.
90, Joaquín Marco, quien era en 1976 director de la colección «Ocnos» y quien, por tanto, apostó por el nombre de un Aridjis apenas conocido, se quejaba en las páginas de $A B C$ del desconocimiento que se seguía teniendo del autor mexicano en nuestro país, pese a su mucha valía: "Homero Aridjis debe ser considerado como uno de los grandes poetas hispanoamericanos contemporáneos, pese a que su obra resulte, como la de tantas voces de la lírica americana de hoy, menos conocida entre nosotros de lo que debiera» (9). Pues lo cierto es que, tras aquellas tentativas de los 70, lo que siguió fue un largo silencio editorial, desde luego no fruto de la causalidad, ya que tiene unas razones precisas que arraigan en los trajines de la política cultural en México, unos hechos que no cabe traer a colación en estas páginas y que podrían ser motivo de un futuro trabajo.

Hoy, hay que celebrarlo, el nombre de Homero Aridjis y su obra empiezan a ser reconocidos en los círculos académicos en España, especialmente en el circuito universitario. En el año 2013, José Carlos Rovira, catedrático de Literatura Hispanoamericana de la Universidad de Alicante, buen conocedor de la poesía hispánica contemporánea, impulsor del Centro de Estudios Literarios Iberoamericanos Mario Benedetti $(\mathrm{CeMaB})$ y de proyectos monumentales como la Biblioteca Virtual Miguel de Cervantes, acogió de forma entusiasta la realización de la Biblioteca de Autor dedicada a Homero Aridjis, inaugurada en 2015. Desde entonces, los investigadores del área de literatura hispanoamericana de la UA (José Carlos Rovira, Carmen Alemany, Eva Valero - directora del $\mathrm{CeMaB}$ - , Víctor Sanchís, Claudia Comes) han apoyado y fomentado la divulgación de la obra del escritor mexicano en Espańa. En mayo de 2017, la UA y el CeMaB organizaron conjuntamente el Seminario "Homero Aridjis: un creador nos introduce en su mundo", dedicado a desvelar las claves de la obra de Aridjis, su poesía, su narrativa, su labor ambientalista. También en la Universidad de Murcia y en la Complutense de Madrid se han dedicado actos que han contribuido a la difusión del autor. Desde la Universidad de Barcelona, Mercedes Serna viene apoyando con convicción esta tarea divulgativa del escritor mexicano en nuestro país, una empresa que ya ha dado sus frutos y que, sin duda, los seguirá dando. En 2017, la editorial Cátedra apostó para la colección «Letras Hispánicas» por el proyecto de edición de una antología poética dedicada a Aridjis, realizada por quien suscribe estas páginas, que se publicó a finales de 2018. Hasta entonces, no se había publicado en España, ni en otro país, ni siquiera en 
su México natal, una edición crítica de la obra del escritor michoacano. El volumen reúne más de un centenar de poemas de la casi treintena de libros de poesía que cuenta en su haber Homero Aridjis, desde el ya lejano Los ojos desdoblados (1960) hasta su poemario más reciente, La poesía llama (2018).

\section{Un diario de sueños}

En 2011 se publica Diario de sueños, un volumen de más de un centenar y medio de poemas del que, sin riesgo alguno, puede decirse que constituye la cima poética de Homero Aridjis. La síntesis estética que logra el autor mexicano, el nivel de maduración del lenguaje poético y de los símbolos, la lectura particular de los mitos, el anclaje con autores y textos del pasado, hacen de este libro un monumento de la poesía hispánica y convierten a Aridjis en un clásico consagrado en vida. Diario de sueños contiene las claves internas de una obra poética que, desde sus inicios, constituye un diálogo continuo con la tradición clásica y moderna. Asimismo, en línea con la poesía moderna, el sujeto hablante que hila los poemas nos muestra la lucha del escritor consigo mismo a cuenta de la propia identidad individual y colectiva, siempre en quiebra, cuestionada, y al cabo falaz, ilusoria.

Como bien describe el título, el volumen se presenta como un diario de sueños. El propio escritor, en una nota aclaratoria inicial, explica cómo surgió este proyecto peculiar: «El viernes 14 de enero de 2005 mi hija Chloe me sugirió escribir el sueño que había tenido esa mañana. Así nació Diario de sueños» (11). La escritura diarística es, sin duda, una de las marcas identificativas de la poesía de madurez de Aridjis. Las primeras muestras las hallamos en Quemar las naves (1975), que contiene una sección titulada «Diario sin fechas", compuesta de 22 poemas. Aunque en un nivel supratextual es un diario fechable si atendemos al curso de los poemarios publicados por Aridjis, de modo que es posible ordenarlo fuera de la ficción poética. Así, Vivir para ver (1977), libro que sigue a Quemar las naves, contiene las siguientes series: «Diario sin fechas» I y II, ambas integradas en una sección más general: «Movimientos». Las series III, IV y V aparecen en Construir la muerte (1982); de la V pasamos a «Diario sin fechas, VII» —es decir, no existe la serie VI-, que se incluye en Imágenes para el fin del milenio (1990); el libro que forma con este un díptico, Nueva expulsión del Paraiso (1990), incluye las series de la VIII a la XI. La número XII se recoge, algo más de una década después, en El ojo de la ballena (2001). Al examinar la continuidad de estas entregas, se comprueba, a tenor de los libros publicados, que ni en El poeta en peligro de extinción (1992) ni en Tiempo de ángeles (1994) ni en Ojos de otro mirar (1998) encuentra continuidad el «Diario sin fechas». Sin embargo, Tiempo de ángeles suple esa ausencia con el «Diario de un ángel», compuesto por media docena de poemas. En cuanto a Ojos de otro mirar, si bien es cierto que no contiene escritos diarísticos como tales, justamente es en este poemario donde se inicia la galería de autorretratos que abarcan las distintas etapas de la vida del escritor, como se verá más adelante. De modo que la dimensión intimista del «yo», autorrepresentado de una u otra forma, no deja de estar presente en la obra poética del autor mexicano entendida como continuum.

Los numerosos textos que conforman las distintas entregas del «Diario sin fechas» responden a un cruce de géneros - el diario y la poesía - que mantienen algunos puntos en común (una escritura íntima susceptible de hacerse pública, la instancia de un "yo" consciente de sí mismo) y presentan a la par unas marcas diferenciales. Para hallar la simbiosis plena entre pulsión poética y escritura diarística habrá que esperar a Diario de sueños, el libro de Aridjis que más se asemejaría a un diario literario propiamente dicho, tal como lo define Álvaro Luque Amo (297), pues una buena parte de los poemas están fechados intratextualmente con exactitud diarística, aunque ello forme parte de la ficción, claro está. En el caso de algún que otro poema, además de señalarse el lugar y la fecha del sueño, e incluso hasta la hora exacta o aproximada del mismo, se nos dan ciertas noticias que ayudan a contextualizar y entender el pasaje soñado ${ }^{3}$. No obstante, tal vez por dejar una puerta abierta a la naturaleza libertaria de los sueńos, el libro incluye una larga serie, compuesta de una treintena de poemas, titulada "Sueños sin fechas»,

3. Así, por ejemplo, el poema «Juan José Arreola juega su última partida» (147) va acompañado de una "Nota», de la que reproducimos una parte: «Este sábado en la mañana soñé con Juan José Arreola. Viejo y desdentado, el escritor me recitaba versos parado delante de una mesa con un tablero de ajedrez». Ello remite a un pasaje autobiográfico, ya que, en efecto, Aridjis, que fue un gran ajedrecista, era invitado frecuentemente en los años 60 por Arreola a jugar al ajedrez en su casa, donde se reunían varios aficionados y jugadores profesionales. Fue de este modo como trabó honda amistad Aridjis con el autor de Confabulario, quien quiso hacer del joven poeta michoacano un campeón mundial de ajedrez. 
un claro guiño al "Diario sin fechas» que va publicando Aridjis por entregas. A fin de cuentas, la poesía, como los sueños, se resiste a ser encorsetada con el rigor de la escritura diarística.

Más allá de que las anotaciones paratextuales pudieran ser veraces, no cabe duda de que Diario de sueños - e igualmente el "Diario sin fechas»- pertenece al género de ficción, así como la poesía misma al formar parte del discurso literario. En realidad, la controversia acerca del estatuto del «yo» en el diario no dista del problema que acecha a la poesía. En ambos discursos, el diarístico y el poético, resulta inevitable reflexionar acerca de si ese "yo» que se presenta como sujeto hablante, muchas veces protagonista, se corresponde con el "yo» de carne y hueso, lo que entendemos por la persona del «autor». ¿Es suficiente que coincidan, en términos onomásticos, dichas identidades? Si aplicásemos la teoría narratológica tanto a las manifestaciones diarísticas como a la poesía, y no hay razón para no hacerlo, concluiríamos que la voz hegemónica del diario es tan ficticia como la del sujeto hablante del poema, por más que estas autoconstrucciones entrañen, como sabemos, una honda verdad. Siendo esto así, todavía resulta más claro si se trata de un "diario poético", como es el caso de Diario de sueños. Comenzando, si se quiere, por el hecho de que, como sucede incluso en el diario personal sin intención literaria, se opera la construcción de un "yo» enunciativo que es una autoficción, lo que de nuevo acerca la escritura diarística a la poesía.

No pocos de los textos que componen el libro llevan inscrita en el título la marca del espacio sueño: «Siempre sueño en un lugar que es otro lugar», «El proyector de sueños», "Hay que soltar los sueños», "Sueño breve», "Sueño de excusas», "Sueño anónimo», «El fin de los sueños», entre algunos ejemplos, aunque otras muchas composiciones tratan de un sueño sin que ello se haga explícito desde el título. Sin embargo, resulta evidente que no todos los poemas incluidos en Diario de sueños responden al reto de recrear, en clave poética, los sueños nocturnos en tanto que proyecciones oníricas. Algunos poemas ni siquiera aparecen fechados, y nada hace pensar que respondan a un sueńo. Pero no es esto lo significativo, sino más bien lo que revela el hecho de titular un libro con el término Diario, que remite a un género preciso y a una tradición que arranca de los diaristas franceses, asentada en nuestra cultura letrada occidental. El último poemario de Aridjis publicado hasta la fecha, La poesía llama (2018), incluye en la parte final una reflexión metapoética bajo el título elocuente «Poesía sobre poesía». En ella, el escritor confiesa:

Mi poesía es un diario íntimo que se ha ido haciendo con los años, con experiencias personales y ajenas, con pensamientos propios y heredados, con lecturas afines y accidentes que estuvieron a punto de matarme, con revelaciones que me han ido soliviantando interior y exteriormente, con discrepancias conmigo mismo, con formas de defensa que han sido maneras de desagraviarme del ambiente hostil que me ha rodeado; y, sobre todo, con una lealtad innegociable a mi estro poético (183).

\section{Autorretratos del «no yo»}

Al examinar los escritos autobiográficos de Aridjis, Patrizia Spinato habla de «autobiografismo onírico» (215). Con más razón convendría aplicar dicho marbete a los poemas que conforman Diario de sueños, donde las ensońaciones espectrales campan a sus anchas. Sirvan como ejemplo estos versos: "Soñé que tres mujeres vestidas / con camisas y enaguas de colores, / me servían en platos de barro negro / un banquete en el Mictlan» (66) ${ }^{4}$; «La noche pasada soñé con mi padre. Le pregunté algunas cosas, sonrió, y dijo nada» (140); "En una noche cerrada, la oscuridad sólida como una lápida, se me apareció Eurípides en un sueño» (145). En cuanto al autobiografismo - dejemos de lado, por el momento, la dimensión onírica-, cabe recordar (¿hace falta?) un hecho insoslayable: que toda literatura es, por defecto, autobiográfica. Dicho esto, en la poesía de Aridjis cobran especial relevancia modalidades discursivas que ponen el foco en la construcción del "yo» en tanto que instancia que sostiene el discurso, la voz, el disfraz del poeta. De una parte, está el diario, que forma una continuidad en la poesía aridjisiana, como se ha visto. Y de otra, los autorretratos, que, sumados en cronología, constituyen otra marca visible de la poética del autor. A diferencia de los diarios, cuya filiación escritural es inequívoca, los retratos que compone Aridjis de sí mismo se inspiran en la pintura, en artistas como Durero, Rembrandt, Goya o Van Gogh, quienes se destacaron en el ejercicio de autorretratarse.

4. El Mictlan es el espacio del inframundo en la mitología azteca. 
La galería de autorretratos que asoma en la obra poética de Aridjis se inicia a finales de los años 90, más tardíamente respecto a la escritura diarística, cuyas primeras muestras datan de mitad de la década del 70 . El libro de autorretratos por excelencia es Ojos de otro mirar (1998), que Aridjis publica a la edad de 58 ańos, y que incluye nada menos que ocho autorretratos: a los 6 años, a los 10, los 11, los 13, los 16, los 54, a los que hay que sumar un "Autorretrato herido" y un «Autorretrato en el portal». A diferencia de las autorrepresentaciones (que no autorretratos) que pueden rastrearse en la poesía de Aridjis de los años 60 y 70, se advierte en la madurez de su escritura una tensión constante entre la construcción y la deconstrucción, entre el «yo» y el «no yo», hasta romperse finalmente en mil pedazos la imagen de sí mismo, liberada al fin de toda representación posible y declarada en fuga. Sin duda, la edad provecta se presta a todo tipo de balances, de inventarios de vida. «Autorretratarse es autoenjuiciarse para sí y para los demás; de la veracidad de esta confesión surgirá una gran verdad o una enorme mentira", afirma Carlos Cid Priego (187).

En vez de hallar una imagen fiable y complaciente del «yo», a medida que se encamina a su senectud Aridjis se autorrepresenta como "no yo", que es la negación del «yo», preanunciado en el «Autorretrato en un espejo", escrito a los 60 años e incluido en $E l$ ojo de la ballena: "Con palabras prestadas de generaciones / difuntas he pintado con detalles / el cuadro de mí mismo, sin hallar mi rostro. // He cumplido sesenta años y todas las distancias / se han concentrado en la luna del espejo, / como si mi ego fuera a caer en un abismo de vidrio" (Aridjis, Ojos 828) ${ }^{5}$.

En Diario de sueños, publicado cuando el escritor ha sobrepasado los 70 ańos, la presencia explícita del «no yo» se hace más notoria, como muestran los títulos «No yo», que aparece por dos veces, y "Cuento de no yo». En el primer "No yo", fechado en París el 14 de julio de 2009, la voz poética que inevitablemente confundimos con Aridjis se refiere a «El extraño que soy dentro de mí». Toda acción es anulada por la negación que da título al poema: «No yo besaré tu boca. / No yo miraré tus ojos» (23). Un detalle de edición interesante es el juego de fotografía a color y su negativo que conforman

5. Resulta reveladora la presencia del espejo en este y en otros de los autorretratos compuestos por Aridjis, como el "Autorretrato herido» o aquellos que se desarrollan en la peluquería, donde el sujeto del poema se ve reflejado en el vidrio. En este detalle del espejo se aprecia la influencia de la pintura en los autorretratos de Aridjis. respectivamente la sobrecubierta (lo que en el argot editorial se denomina "la camiseta») y la cubierta del libro. En la sobrecubierta aparece, en la contraportada, una imagen a color del escritor caminando por el campo bajo un cielo azul con nubes, con los cerros al fondo. Una fotografía tomada por su hija Chloe, según consta en los créditos. Pero, al despojar al libro de la sobrecubierta, lo que se ve, tanto en portada como en contraportada, es el negativo de la foto. Es decir, el «no yo» del escritor que luego encontramos en varios poemas del libro. Por tanto, Diario de sueños parte de un principio conceptual referido a una instancia del «yo» que protagoniza y firma los textos. Desde esta perspectiva ontológica, obviamente este "no yo» implica un "no tú», de manera que toda realidad humana resulta ilusoria, fugaz, intrascendente, como muestra el segundo «No yo»:

«Ahora o mañana, desnudos o vestidos nos desvaneceremos en el centro o en la periferia de nuestro laberinto interior», dijo ella, y se desvaneció (52).

La culminación de este proceso deconstructivo la hallamos en el poema "Epílogo», que es un resumen de vida y que nos habla de una ética personal. En esta ocasión, en vez de trabajar Aridjis con la dimensión artístico-literaria del autorretrato, a sus casi 70 años (el poema está fechado en México el 10 de agosto de 2009) el escritor se ve a sí mismo, con espanto, convertido en monumento de piedra o bronce. El poema se abre con la cita Exegi monumentum, tomada de uno de los carmina más conocidos de Horacio, que comienza así: «Exegi monumentum aere perennius» (Odas, Libro III). En esta conocida oda horaciana, el poeta latino aventura que su obra perdurará en el tiempo: "He levantado un monumento más duradero que el bronce». Con ello, Horacio hace honor a una de las grandes preocupaciones de la latinidad, que pervive a lo largo de la Edad Media: el tema de la fama postrera y la perdurabilidad a través de la memoria colectiva. Aridjis dialoga de este modo con la tradición, en este caso con uno de los más grandes poetas de la antigua Roma, y plantea, frente al tema de la fama imperecedera que todo poeta persigue, una alternativa a contracorriente de la vanidad típica del artista: el rechazo a la monumentalización. Pues este hecho, pareciera querer decirnos Aridjis, supondría una muerte en vida, su inoperancia como hombre de letras y de acción. No obstante, más allá de esta lectura que enfoca en la imagen de autor, el posicionamiento ético y estético que el sujeto hablante del 
poema postula va acorde con la idea aridjisiana de la imposibilidad de fijar una imagen de sí mismo, que de cualquier modo resultaría una identidad impostada: «He bajado de mi monumento. / Rompí el espejo, no creo en mí mismo. / Soy más fugitivo que el aire / y menos duradero que las ruinas» (149).

En definitiva, las páginas de este Diario nocturnal abren los interrogantes sobre la propia identidad, enfrentada en presente al concepto mismo de realidad y a las incertidumbres sobre el pasado y el futuro. Una identidad siempre en precario, puesta en tela de juicio, huidiza, fugitiva, pero que, al ser abordada en Diario de sueños desde el espacio espectral, onírico, revela su verdad desnuda y descarnada: «Hay que soltar los sueños / Hay que dejarse ir sin ataduras / a los abismos de nosotros mismos», postula la voz poética de Aridjis (69).

Amén de estas autorrepresentaciones en negativo protagonizadas por el "no yo», Diario de sueños nos ofrece, como es costumbre en la poesía de madurez de Aridjis, un autorretrato en positivo, en la línea de los anteriores libros a partir de Ojos de otro mirar (1998). Esta vez se trata de un autorretrato "A los setenta», fechado en San Francisco el 6 de abril de 2010 (por tanto, posterior al «Epílogo») y dedicado a su esposa Betty Ferber. Un autorretrato que, cargado de un optimismo apremiante por causa de la edad, se postula como contradiscurso del «no yo»:

\begin{abstract}
A los setenta, amar como si fuera la primera vez.
Vivir, como si fuera el último minuto.

Mirar, como si todo fuese caza que huye alrededor.

Defender las esferas de la vida como a mí mismo.

$[\ldots]$

A los setenta, no estar triste bajo la luz que mi alma no se cierre, no se seque, no se amargue: abrazar el aire, el agua, la tierra,

los cuerpos, las cosas, el espacio y el tiempo (100).
\end{abstract}

\section{Mitología fusión}

Otro de los elementos presentes en Diario de sueños que conforman la poética del autor se refiere a una particular relectura del mito. En la obra de Aridjis

6. La frase «no estar triste bajo la luz» remite a un verso de Dante Alighieri, el poeta dilecto de Aridjis, según este ha confesado en más de una ocasión. Un verso que el mexicano toma como un mandato, un principio vital. confluyen dos tradiciones: la griega, por parte de padre; y la azteca y maya, por vía materna. Nicias Aridjis Teologou, padre del escritor, llegó a México en 1926 por el puerto de Veracruz, cuando aún estaban candentes los rescoldos de la sangrienta Revolución. En una visita a la capital conoció a Josefina Fuentes Zaldívar, oriunda de Contepec, en el estado de Michoacán, y ambos se instalaron en el pueblo, donde montaron un almacén de tejidos y todo tipo de enseres para el hogar y el campo. Aunque el nombre de Homero Aridjis, de indudable raíz griega, nada tiene que ver con la onomástica hispano-mexicana, el escritor nació y creció en las costumbres del México de su tiempo. Pero la influencia del padre, los relatos que este contaba de su Grecia natal, la añoranza de su tierra lejana, todo ello pronto hizo mella en la mente creativa de Aridjis ("Antes que en brazos de la Parca helada / crucemos separados los umbrales del Hades, [...] quiero, padre mío, volver contigo a la huerta de mi infancia y, escondidos de todos, / cortar los higos blancos de Esmirna»" ${ }^{7}$ ), de manera que los mitos helénicos, releídos desde el presente y trasplantados a una nueva geografía, empiezan a asomar en su obra poética desde muy temprano. Uno de sus primeros libros se titula, no en balde, Perséfone.

A la par de ello, los mitos aztecas han estado muy presentes en la obra poética, narrativa y teatral de Aridjis: Huitzilopochtli, Quetzalcoatl, Tezcatlipoca, Catlicue, dioses de la mitología mexica; la leyenda del Quinto Sol, que anuncia la destrucción del mundo a causa de un terrible terremoto; la fundación de la ciudad México-Tenochtitlan, todos estos mitos, fábulas y leyendas, y asimismo los que rodean la conquista de Hernán Cortés y el reino de la Nueva España, cobran vida en la poesía de Aridjis, concretamente a partir de su libro Quemar las naves (1975), cuando irrumpen como temas poéticos la empresa de Cortés (el título del poemario alude, de hecho, a un conocido pasaje atribuido al conquistador extremeño) y el mundo de los mexicas, del que fue señor y dueño el tlatoani Moctezuma.

Ambas mitologías, la helénica y la azteca, conviven en la obra poética de Homero Aridjis, pero apenas se fusionan y entremezclan, como si se tratase de mundos separados destinados a no encontrarse, siguiendo en esto los azares de la historia misma. En cambio, en Diario de sueños se produce la intersección de ambas tradiciones, una simbiosis lograda que

7. Estos versos pertenecen al poema «Los higos de Esmirna», de Diario de sueños (94), que Aridjis dedica a su padre. 
tendrá su continuación en el siguiente poemario, $\mathrm{Del}$ cielo y sus maravillas, de la tierra y sus miserias (2013), en textos como «El pequeño Edipo», «El Tántalo» o «Midas y su novia en la Pirámide del Sol», que bien podrían haber formado parte de Diario. De este, cabría destacar, entre otros, los poemas que tienen como protagonista a Midas, aquel histórico rey de Frigia hecho mito, quien, según relata Ovidio en sus Metamorfosis (Libro XI, 85-93), tenía el don de convertir en oro todo cuanto tocaba, pero que, se dice, murió de hambre al no poder ingerir los alimentos que al tacto quedaban transformados en el preciado metal. En la relectura del mito, Midas representa en la imaginación creativa de Aridjis al empresario multimillonario, desde luego que corrupto, despiadado, indiferente a la pobreza, amigo de presidentes, ministros y secretarios, que en México campan con total impunidad, protegidos por los políticos y el narco. Aunque Aridjis trasplanta el mito a la realidad del México actual, las imágenes de opulencia obscena podrían corresponder a otras geografías conocidas, en un mundo, el nuestro, donde, según muestra el coeficiente de Gini, la brecha entre ricos y pobres es cada vez mayor en aquellos países (con EE. UU. y Gran Bretaña a la cabeza) en donde se ha desatendido la importancia de regular los mercados y en los que, mientras la clase media soporta la constante subida de impuestos, las grandes fortunas encuentran fructuosos modos de evadir el fisco. La serie de poemas «Imagínate, rey Midas», «Midas en el espejo», "Midas en la piscina», "En boca de un viejo amigo", "Musgo» y "Midas» retrata con agudeza la imagen prototípica del empresario corrupto y constituye una denuncia de la situación de impunidad de toda clase de delitos (desde el narcotráfico hasta el asesinato de mujeres y niñas) que se vive en el México convulso, uno de los países de mayor peligrosidad del mundo, como refleja el informe Mexico Peace Index 2018 del Institute for Economics \& Peace ${ }^{8}$.

En «Imagínate, rey Midas» (71), el personaje mítico, con todo su oro a cuestas («Imagínate, rey Midas, / que esas ruinas que ves fuesen de oro, / y esos ríos que bajan por las laderas / de los cerros fuesen de oro, / y las nubes del cielo, / los árboles del bosque, / y las mujeres fuesen de oro, / y los mismos pobres fuesen de oro»), es derrotado por el dios Sol, pues, al mirarlo, Midas

8. Para una mayor información acerca de las tipologías de la violencia y sus causas en el espacio mexicano, véanse los trabajos del libro coordinado por Nelson Arteaga Botello Violencia en México (Madrid: La Catarata, 2013). queda ciego: «Imagínate, rey Midas, todo ese oro, / y tú preso en un cuerpo muerto. / Toda esa riqueza, y tú ceniza, y tú nada». Puesto que la erótica del poder se recrea en la contemplación de la riqueza acumulada, la ceguera constituye un castigo apropiado, una venganza divina contra la ambición sin límites. En otro poema, «Midas» (78), el Aridjis ecologista nos recuerda que el poder de unos conlleva la pobreza de muchos, pero no solo eso: incendia bosques, contamina ríos, dinamita montańas. Y les recuerda, a esos reyes de la banca, del petróleo, del narco, que un día vendrá la muerte, la gran igualadora, y entonces se oirá cantar al viento: «Me importas madre, rey Midas, / rey de los bancos, las putas y la mierda». Pero, sin duda, es en el arranque del poema "Midas en la piscina» (73) donde mejor reconocemos el comportamiento obsceno y egoísta del rico indecente, o del político corrupto, lo mismo en México que en Nueva York, en España que en Reino Unido, en Rusia que en Suiza. El poema dice así: «En la ciudad no había agua, / pero Midas en su piscina olímpica nadaba / como si toda el agua de la ciudad fuese suya». Aridjis no escatima la crítica a la moral hipócrita y retorcida del poderoso, que lava su imagen pública y hace autopropaganda con su apoyo a las causas sociales:

Había contado las ganancias del día,

y estaba feliz porque pensaba que la gente

estaba feliz porque él había hecho un millón más,

y porque con sus millones había hecho más pobres y ahora podía ayudar a los pobres.

En sus sueños de justicia, Aridjis imagina las mil formas de castigo eterno a los Midas de hoy, portadores del Apocalipsis moderno que nos llega ya no por la mano de Dios, como el anunciado por Juan de Patmos, sino por obra del hombre, principal actor de la ecología global (Aridjis y Ferber 432). Atravesando las paredes del gym donde el rey de los banqueros cultiva su imagen, la voz del viejo poeta le susurra: «Midas, / cuando al inframundo bajes, / el dios perro te dirá: 'No te daremos de comer ni de beber, / pero toda la nada que hay aquí es tuya'» (72).

Sin embargo, a la vez que Aridjis lanza sus dardos contra la opulencia desmedida e imagina, en sueños, las múltiples formas de castigo, señala la estupidez de una sociedad que ha cambiado sus ideales de grandeza - el saber, la ciencia y la cultura - por nuevos clichés de éxito social: el rico banquero, el deportista mediático, la bella modelo, el cantante de moda, el famoso de turno que se pasea por los platós de televisión y es encumbrado en las redes sociales. No es este, desde luego, un mundo para poetas. Así, Midas 
sabe que «mientras los aspirantes a millonarios / realizan su sueño, los menos ricos / y los más pobres me admiran, / porque la riqueza ajena / es la satisfacción de los tontos».

\section{México, violencia sin fin}

No solo pone Aridjis el foco en la corrupción de empresarios y políticos, ambos mezclados en un mismo consorcio. Diario de sueños mira de frente a otro de los asuntos más preocupantes del México actual: la violencia descarnada, que crece ańo tras año y se cierne sobre determinados colectivos. Entre estos están las mujeres y niñas que son secuestradas y asesinadas a diario, sin rastro de los captores y criminales. Pero también los periodistas que se atreven a desafiar la ley del silencio impuesta por los narcos en connivencia con las fuerzas del orden y los políticos corruptos. En 2018, México fue el segundo país del mundo donde fueron aniquilados más profesionales de la información, después de Afganistán y seguido de Siria, según informa la agencia Efe. Una violencia que en tiempos del presidente Peña Nieto alcanzó cotas demasiado altas, pero que viene de lejos en tanto que fenómeno social. A tal punto que se ha convertido en tradición, alimentada por la guerra de los narcos.

De nuevo, Aridjis se vale de los mitos antiguos para tratar un problema candente en el siglo XxI. Muchos son los poemas que remiten a la mitología azteca para hablar de la violencia presente, pero, por su relevancia respecto a las ideas del autor, nos detendremos en dos en concreto: "La violencia comenzó con los dioses» $\mathrm{y}$ «Somos hijos de dioses crueles» (58 y 64). En el primero de ellos, una composición breve fechada en París en 2009, Aridjis señala la genealogía de la violencia mexicana, que va inscrita en el título y que es, a su vez, una variante del primer verso:

La violencia en México comenzó con los dioses.

Antes de que hubiera ciudades y templos

ya había desmembrados, desollados y decapitados,

en los ritos del alba. Los Painales?

sicarios de nuestro señor Huitzilopochtli,

ya descendían de los cerros

con un corazón humeante en las manos.

9. En la mitología azteca, los Painales son dioses menores de la guerra que están al servicio de Huitzilopochtli, una de las deidades principales del México prehispánico.
El poema es interesante por la tesis que postula, y porque se desvincula de la corriente hispanofóbica que afirma y defiende que todos los males de México, incluida la violencia desmedida, provienen de los españoles y su cruenta conquista. Que no fue una conquista ni mucho pacífica es algo sabido; pero no fundaron aquellos rudos soldados la violencia en aquel territorio que llamaron Nueva Espańa, como demuestran los estudios más serios sobre las comunidades prehispánicas de Mesoamérica. Desde esta óptica, Aridjis se retrotrae a los ritos sangrientos de los aztecas, quienes, entre otras prácticas religiosas, arrancaban el corazón de sus cautivos con un puñal de obsidiana y se lo comían en crudo, aún palpitante («descendían de los cerros / con un corazón humeante en las manos»). Lo interesante de esta composición es el anacronismo pretendido (pero en poesía todo es posible) que se deriva del uso de la palabra "sicarios", que asociamos a un contexto más próximo a nosotros, el siglo xx y el xxi, y a una práctica determinada: el crimen organizado. De un modo implícito, el escritor mexicano nos lleva del pasado ancestral al presente inmediato y viceversa, trazando con ello una línea de continuidad de la violencia.

Para comprender en una mayor dimensión este texto, hemos de ponerlo en relación con otro poema del libro, apenas media docena de páginas más adelante: "Somos hijos de dioses crueles». Resulta interesante la estructura circular que opera en esta composición, que comienza afirmando «Somos hijos de dioses crueles» y termina concluyendo «Somos padres de dioses crueles». De modo que no es una simple estructura, esta encierra una idea de circularidad: la violencia sin fin. De ahí que, al referirse la voz poética a la civilización azteca, afirme: "Aún no se desvanece la sangre en sus altares». No es infrecuente en la poesía aridjisiana, y aun menos en este Diario de sueños, ver pulular por la Ciudad de México o los pueblos de provincia a los espectros del pasado, que, en la mente imaginativa del poeta, siguen viviendo en el presente. Es esta, sin duda, una manera de decir que las cosas no han cambiado mucho desde tiempo inmemorial. Si en el poema "Jinetes» de Vivir para ver (1977) veíamos a los conquistadores españoles como seres fantasmales atravesar las costuras del tiempo y cruzar a galope tendido por el presente:

Hernán Cortés en su caballo zaino

Pedro Alvarado en su yegua alazana

Francisco de Montejo en su alazán tostado

llegaron un día del mar 
y desde entonces por los llanos polvorientos

a través de vivos y de muertos

sin mañana y sin noche

no dejan de galopar hacia la luz.

en el poema «Somos hijos de dioses crueles» de Diario de sueños son las sombras de los sacerdotes aztecas las que regresan una y otra vez al México de hoy y se instalan en organizaciones criminales: «Sus espectros andan en nuestras ciudades / vestidos de sicario». De nuevo, el término «sicario» recontextualiza el poema y lo acerca a nuestro presente. El mensaje que nos lanza Aridjis es, a todas luces, pesimista: "Aunque se vayan de esta tierra a otra tierra, / volveremos a procrearlos, ellos volverán a emerger / de nuestro adentro, atroces, despiadados, / llevando nuestro rostro. Somos padres de dioses crueles». Una idea, esta del tiempo circular, que graba la violencia en piedra, para condena de las generaciones futuras. Larga vida a la Santa Muerte.

\section{Coda final}

Estas breves páginas ni mucho menos recogen en toda su dimensión estética e histórica un poemario excelente como es Diario de sueños, ni dan cuenta de la diversidad temática y compositiva que ofrecen los más de 150 poemas que conforman el libro. No obstante, se apuntan y tratan en el presente artículo algunas líneas esenciales de la poesía de Homero Aridjis que, perfiladas a lo largo de décadas, vienen a cuajar en este diario de sueños, resumen y cénit de una poética singular, la de un autor de fuste curtido en los ricos ańos 60 de la cultura mexicana, en medio del fuego cruzado de los debates estéticos e ideológicos que tuvieron lugar en aquel entonces dentro y fuera de México.

Transcurridas la década de 1960 y una buena parte de la siguiente, el marcado erotismo que signó la primera poesía de Aridjis se difumina y pasa a un segundo plano para dar protagonismo a la historia y al mito. El escritor michoacano, sin embargo, no se conformará con lo que Milan Kundera denominó «el pequeńo contexto»: el pueblo, la provincia, el país. A sabiendas de que la poesía es remisa a los corsés de la territorialidad, y sin duda consciente de que su ascendencia griega por vía paterna, y su nombre mismo, Homero, lo legitiman más si cabe como heredero de un contexto mayor, el de la cultura occidental, Aridjis se lanza a explorar las posibilidades del mito clásico, que se funde con la historia y los mitos del México antiguo proyectados en nuestro tiempo. Junto a ello, y superada la erótica de la otredad que convierte al ser amado en el objeto único, emerge en su poesía el problema —ontológico, estético—- de la propia identidad, por momentos cuestionada, luego negada y, finalmente, dinamitada hasta hacerse añicos la imagen de sí mismo. La escritura de senectud, es cierto, suele estar poblada por los fantasmas del pasado, y en este sentido, en Diario de sueños el autor ajusta cuentas con su propia vida: sus ancestros, su niñez y adolescencia en Contepec, el descubrimiento del amor, de la naturaleza, de la poesía, del cine. Sin embargo, por su talante inconformista y combativo, el Aridjis más beligerante no pierde de vista el presente que mira al futuro cercano, un futuro incierto, el de la humanidad, el de nuestro planeta, con el que el escritor se siente íntimamente comprometido desde una perspectiva humana, social, ecológica, poética.

Los materiales eclécticos que a lo largo de los años arrastra el río caudaloso de la poesía aridjisiana, sedimentan al cabo en un libro como Diario de sueños, pleno de madurez poética, genuino. Ahora bien, ¿qué es lo que realmente convierte a Homero Aridjis en un autor original digno de aparecer en el Parnaso contemporáneo? Parece poco menos que irreverente plantear esta cuestión en las últimas líneas de este trabajo, a sabiendas de que una pregunta de este calado exige una respuesta de igual tamańo. Pero, a falta de más espacio, cabe siquiera ofrecer una punta del ovillo sujeta de la mano de T.S. Eliot, quien, con la agudeza crítica que siempre lo caracterizó, señala que a menudo ponemos el acento en la originalidad de un autor con la errática creencia de que es ahí donde debemos prestar toda nuestra atención. «No obstante, si nos aproximamos a un poeta sin este prejuicio, con frecuencia encontramos que no solo las mejores partes de su obra, sino las más individuales, acaso resulten aquellas en las que los poetas muertos, sus ancestros, confirman su inmortalidad más vigorosamente» (Eliot 65). Es así como, de aquel Homero a este otro, se renueva el espíritu ecuménico e innominado que convencionalmente llamamos "poeta», que es encarnación de la poesía intemporal. 


\section{Bibliografía}

Aridjis, Homero. Ojos de otro mirar. Poesía 1960-2001. México: FCE, 2002.

Aridjis, Homero. Diario de sueños. México: FCE, 2011. Aridjis, Homero. Biblioteca Homero Aridjis. Aníbal Salazar Anglada y Laurence Pagacz (dirs.). Alicante: Biblioteca Virtual Miguel de Cervantes, 2015. http:// www.cervantesvirtual.com/portales/homero_aridjis/.

Aridjis, Homero. La poesía llama. México: FCE, 2018.

Aridjis, Homero. Antología poética (1960-2018). Ed. de Aníbal Salazar Anglada. Madrid: Cátedra, 2018.

Aridjis, Homero y Ferber, Betty. Noticias de la tierra. México: Debate, 2012.

Arteaga Botello, Nelson (ed.). Violencia en México. Madrid: La Catarata, 2013.

Cid Priego, Carlos. «Algunas reflexiones sobre el autorretrato». Liño. Revista anual de historia del arte, 5, (1985): 177-204.

EFE. «México y Afganistán lideran la lista de periodistas asesinados en 2018». 17 de diciembre 2018. https://www.efe.com/efe/espana/sociedad/mexicoy-afganistan-lideran-la-lista-de-periodistas-asesina- dos-en-2018/10004-3844932. Consultado el 12 de febrero de 2019.

Eliot, T.S. Lo clásico y el talento individual. México: UNAM, 2004.

Institute for Economics \& Peace. Mexico Peace Index 2018. http://visionofhumanity.org/indexes/mexicopeace-index/. Consultado el 10 de febrero de 2019.

LuQUe AMO, Álvaro. «El diario personal en la literatura: teoría del diario literario». Castilla. Estudios Literarios, 7, (2016): 273-306.

Marco, Joaquín. «Homero Aridjis. Antología poética (1960-1994). México: FCE, 1994». ABC Cultural. 9 de septiembre 1994: 9.

Peri Rossi, Cristina. «Panerotismo en la poesía de Homero Aridjis». Thomas Stauder (ed.). La luz queda en el aire: estudios internacionales en torno a Homero Aridjis. Frankfurt am Main-Madrid: VervuertIberoamericana, 2005: 109-114.

Spinatto, Patrizia. «El mundo poético de Homero Aridjis». Carmen Alemany (ed.). Artes poéticas mexicanas. Guadalajara, México: Universidad de Guadalajara, 2015: 213-233. 